\title{
Scaffolding Plays A Macro Role in Early Childhood Educational
}

\author{
Susilahat $^{1}$, Helfi Gustia ${ }^{2}$, Muhammad Sahrul ${ }^{3}$ \\ \{susilahati@gmail.com ${ }^{1}$, helfigustia@yahoo.com², muhammad.sahrul@umj.ac.id ${ }^{3}$ \} \\ ${ }^{1}$ Social Welfare Departmenet, University of Muhammadiyah Jakarta, Jl. KH. Ahmad Dahlan \\ Cirendeu Ciputat Tangerang Selatan, Banten 15419, Indonesia. \\ 2 Agriculture Department, University of Muhammadiyah Jakarta, Jl. KH. Ahmad Dahlan \\ Cirendeu Ciputat Tangerang Selatan, Banten 15419, Indonesia. \\ ${ }^{3}$ Social Welfare Departmenet, University of Muhammadiyah Jakarta, Jl. KH. Ahmad Dahlan \\ Cirendeu Ciputat Tangerang Selatan, Banten 15419, Indonesia.
}

\begin{abstract}
The implementation of learning in education for young learners is carried out through playing in the center/area/angle as the Minister of Education and Culture Regulation of the Republic of Indonesia Number 137 of 2014 concerning National Standards for Education for Young Learners. In playing theory, there are 3 types of play, they are playing sensorimotor, playing development and playing roles. In order for play to be meaningful for children, a foundation of playing is called Scaffolding. In the first study, found a variety of local limitations and constraints in the application of Scaffolding to a macro role-playing. In this second study, the application of scaffolding is more focused on the setting of the game, the type of game that meets the density and intensity and the story script that matches the theme based on the potential of a kindergarten. The formulation of the model in this study was carried out through intensive interviews with teachers, centre teachers and principals, repeatedly observing and Focus Group Discussion involving the parties. This model test has produced a macro role-playing model that matches local potential and eliminates limitations that are generally present in Education for Young Learners in South Tangerang. These innovations were found to be beneficial for young learners learning through macro roleplaying. The specific target of this second research is the discovery of new innovations in the application of Scaffolding to role-playing that are in line with local potential without overriding the principles of the application of scaffolding and the principles of a macro role-playing to fulfil the needs of children's development.
\end{abstract}

Keywords: scaffolding, macro play, education for young learners, teacher's role

\section{Introduction}

The number of Education for Young Learners institutions in various provinces continues to increase as stated in the Ministry of Education and Culture of Republic of Indonesia's Education for Young Learners reference data, including the number of Education for Young Learners in South Tangerang. However, it seems that it has not been followed by the prevalence of the quality of learning applied. From the initial survey of play-based learning at the Education for Young Learners Institution in South Tangerang, in general, it has not implemented a programmed and planned playing method. This means that Education for Young Learners institutions have not fully followed the recommendations of Regulation of the Minister of Education and Culture (Permendikbud) number 137 of 2014 concerning National 
Standards for Education for Young Learners stating that the implementation of learning in Education Early Childhood Education is carried out through playing in centers/areas/corners.

One method of play-based learning is Role Playing. The concept is clear, contains the principle of playing meaningfully, and have measurable goals. The benefits of role-playing are so significant for the optimization of early childhood development. Play a role in early childhood is playing pretend. Almost every early childhood never did play pretend, but the problem plays pretend that played such children are less, even not get support a planned and programmed by teachers and institutions of Education for Young Learners or adults around them.

Role play is not yet the chosen learning model, because it is feared that playing the role will be difficult, complicated, troublesome and expensive and requires extensive room facilities. In addition, managers and educators, as well as parents, also do not understand yet the benefits of playing a role for optimizing child development. Even though all of those who are feared can find a solution, as long as it is still in accordance with the principles of education for young learners. One solution is to look for innovations in the application of Scaffolding role play that can be easily carried out by teachers and managers of Education for Young Learners institutions.

The focus of the research is how macro scaffolding role play in Education for Young Learners can be applied. The sub-focus of the research are: (1) How is the application scaffolding in the playing environment, before play, during play and after play, (2) How is the role of teachers in each scaffolding role-playing, (3) How is the social service support for the implementation of scaffolding role-playing (4) What is the manager's support Education for Young Learners in the application of scaffolding role-playing. The specific objective of this research is the discovery of technology innovations for young learners in their learning through the application of the macro scaffolding role playing is able to accommodate all the limitations that exist in Education for Young Learners in general by exploring the potential of Education for Young Learners. Data taken from the findings of the study and then modified to accommodate various limitations and potential. The study was conducted in two kindergarten institutions that have implemented Macro Role Play, then conducted a Focus Group Discussion, in-depth interviews, observation and observation of documents and related reference studies.

\section{Orientation of Education for Young Learners}

Orientation education for young learners continues to roll out to be understood and implemented. Various policies in Indonesia continue to support various efforts to develop education for young learners. Even so, there are still many who understand that education for young learners is an education that enables children to be able to read, write and count fluently. Even if there are playing activities, this is done separately with learning activities. This shows that the institution of Education for Young Learners has not applied yet the full playing method. Montessori (2013) the character of the child as a learner states that true learning arises from the freedom of children to choose their activities and to perfect them also requires a re-formulation of what the teacher means. The application of education for young learners' programs is essential to apply theory to practice. (George S. Morisson, 2012). Development of learning programs for education for young learners then oriented to principles; oriented to child development, children's needs, playing while learning, integrated stimulation, conducive environment, using thematic, active, creative, innovative, effective and enjoyable approaches, using various media and learning resources, and democratic learning 
(Trianto, 2013). It is emphasized that one of the fundamental principles in education for young learners is the importance of games for learning and development of children (Cathy Nutbrown and Peter Clough, 2015). The next orientation is emphasized by directing that education for young learners' curriculum should be based on child development known as Developmentally Appropriate Practice (Marjorie J. Kostelnik, Anne K. Soederman and Alice Phipps Whiren, 2017).

\subsection{Density and Intensity of Play}

In role-playing, it should be noted about the intensity and density of play. Intensity is the amount of time a child needs for the experience of playing in three types of play throughout play. The concept of intensity emphasizes the amount of time it takes for children to move through the stages of cognitive, social, emotional, and physical development needed to participate. Meanwhile, Density is a variety of ways from each type of play that is provided to support the child's play experience. The concept of density emphasizes the different activities that provided for young learners. To meet the intensity and density of the gaming experience, it takes at least an hour to play this role. Phelps (1986) and Stannard (2002), suggest there should be three playgrounds for each child for development at the age of two, three, or four years. If one classroom has 20 children who will move around the room to select activities, there must be sixty places planned to play.

\subsection{Foundation}

A pleasant playing experience with materials, objects, other children, and adult attention helps children develop physically, emotionally, cognitively, and socially. The high-quality playing environment for young learners supports three types of play that are known in young learners' research (Weikart, Rodgers, \& Adcock, 1971) and theories from Erik Erikson, Jean Piaget, Lev Vygotsky and Anna Freud. To develop a quality playing experience, it is necessary to provide scaffolding in play activities. Many theories about play are used as the basis for the implementation of young learners learning. One of them is the results of research from CCRT which has carefully considered the stages of quality playing experience. The playing environment foundation includes a foundation of experience before playing, a foundation for each child's playing experience. In providing a foundation it was found that the intensity and the density of playing experience in variety and opportunity.

\subsection{The Nature of Scaffolding}

The definition of foundation (scaffolding) is changing support during learning activities, where more skilled partners adjust support for the level of children's performance at that time. More support will be given when the task is new and diminishes in line with the increase in children's abilities. Thus giving a foundation can instill self-control and independence in children. According to Vygotsky, students can develop thinking skills to a higher level when they get guidance (scaffolding) from someone more expert or through colleagues who have higher abilities. Likewise, Piaget argues that students will get enlightenment of new ideas from someone who has knowledge or has expertise. Scaffolding is prepared by the learner to not change the nature or level of difficulty of the task, but with scaffolding supplied enable learners to successfully complete the task. So the scaffolding is changing support during learning activities, where partners are more skilled at adjusting support for the current level of children's performance. More support is given when the task is still new: less support when the child's ability has increased, thus giving a foundation can instill self-control and independence 
of the child. Foundation is a fickle support adjusted to the development of a child who is given as a foundation to achieve higher growth. The foundation is done by using 4 types of scaffolding to support children's development, namely; (1) Playgrounds Foundation, (2) Foundation before playing, (3) Foundation during playing, and (4) foundation after playing.

\section{Method}

This research is located at Pembina Kindergarten, Pamulang, South Tangerang, using a qualitative research approach. The selection of kindergartens was carried out after previously investigating two kindergartens representing public and private kindergartens. In the Private Kindergarten, a series of scaffolding applications have been found. The implementation starts from scenarios, playing settings and activity settings, assistive devices such as Educational Games and facilities are adequate. In the Public Kindergarten, data was collected through observation, in-depth interviews with teachers, Focus Group Discussion with teachers from Kindergarten that had role-playing, principals, Himapaud in South Tangerang, experts and education service officials of the South Tangerang. Data analysis was done formatively with evaluations to analyze the trial of concepts and innovations in the application of scaffolding at each play activity in each play setting. The collected data was analyzed through categorization and classification of the research focus and sub-focus of the study which included: playgrounds foundation, foundation before playing, foundation while playing and foundation after playing which was carried out in role playing. With a variety of limitations, it was found to be observed how the ability of Pembina Kindergarten in implementing scaffolding played a role.

\section{Results \& Discussion}

Scaffolding role-playing can be implemented with attention and consider the limitations of the Education for Young Learners institutions everywhere, as long as the play setting allows children to play. In this second year study, it was investigated how the application of Scaffolding that has been modified in accordance with the theory and conditions of the situation at the research site. The theme chosen is a theme that they often use, namely: "My Home is My Paradise". In the first year research, it was found that the application of macro scaffolding role-playing that was not optimal in stimulating children's abilities. Macro roleplaying has not been able to show four optimal playing environments. On the first foundation, the initial management of the macro role playing environment has not calculated yet the place of play provided by a number of three playgrounds for each child. In addition, the experience of density which is a tool and material has not been well planned and the intensity of playing time is still not consistent. On the second foundation, the foundation before playing was found in the absence of a story script about "My Home is My Paradise", so that it cannot be offered to children who act as what. Next on the third foundation, namely the foundation when playing found the role of teachers who have not been optimal in providing stimuli to children, so that the increase in the ability of children above the average ability level cannot be found. Next on the fourth foundation, namely the foundation after playing, found in the implementation recalling the role of the teacher has not been optimal in providing rounding up the macro role-playing for each child. From the research results of the above, researchers formulated the macro scaffolding role-playing model by considering the potentials and weaknesses that found in the field of research and supporting theories. 


\subsection{Playgrounds Foundation}

Environment of macro role-playing is designed to create a playground that is conducive for children. A conducive environment will make children play comfortably. Children will understand when doing something. This playground foundation has been adapted to potential such as institutional status, as Pembina Kindergarten, existing Human Resources and limitations possessed such as the lack of storytelling, yet institutionalizing the implementation of macro role playing, and the demands of parents of reading programs, writing, and counting.

a. Manage the start of the playground with enough ingredients (three playgrounds for each child): In the theme of My Home is My Paradise, there are settings for playing and each setting may be played by more than 1 child, so that each child has 3 opportunities to play. Therefore, it is necessary to make a model of the playground foundation that has an initial management of the role-playing environment by calculating the playground that has three playgrounds for each child. The theme "My Home is My Paradise" should have at least 4 play settings, namely family room settings, dining room settings, kitchen room settings and mini market settings. Playing activities include visiting, cooking, washing dishes, bathing babies, eating together, shopping. Each activity is played by a minimum of two children.

b. Plan the intensity and density of experience: To meet the intensity and density of play experience, it takes 1 hour to play this role. Intensity is the amount of time a child needs for the experience of playing in three types of play throughout play. The concept of intensity emphasizes the amount of time it takes for children to move through the stages of cognitive, social, emotional, and physical development needed to participate. Meanwhile, density is the various ways in which each type of play is provided to support the child's play experience. The concept of density emphasizes the different activities provided for young learners. Because of the limitations of the room, one class was dealt with divided by two groups with a calculation of 1 hour each. Children in the first group, preparing to play a role, while the second group, given a busy drawing, in the arena outside the center of role-playing. This condition does not disturb role-playing in the role-playing center.

c. Having various materials that support the macro role play: tables, chairs, vases, magazines, newspapers, tablecloths, mukena, sarongs, skullcaps, prayer mats, according to the number of children in groups, tables, chairs, spoons, forks, plates, glasses fruits, vegetables, fish, kettle filled with water, small rice basket, mini iron board, iron, some clothes, stoves, small chairs, frying pans, pots, spatulas, plastic vegetables and fruits, fish, etc., two places: cash register, counting machine, toy money, bottles, used boxes, shopping plastic bags, plastic vegetables and fruits, adult size used clothes belonging to the father or mother of students. Macro role play materials, parents can volunteer donations of used goods as household furniture, clean bottles used for perfume, powder, liquid soap, shampoo that has been washed and sterile.

d. Arranging playing opportunities to support positive social relations: Setting a macro role-playing, arranged so that each child can be accommodated social skills, according to the stage of development of each child. Setting a macro role-playing with the theme My Home is My Paradise is made by setting a family room, dining room, kitchen room, bathroom room, market. This setting is a macro role-playing material that can support 4 children's social skills. The four social skills are playing alone, which is called the solitary. Solitary is a situation where children are involved in playing activities themselves. In addition, this place can also support children in 
playing side by side which is also called parallel. Parallel is a situation where children can form social relations as often seen in social relations, so that social relations in children can occur. Another thing supported by this place of play is support for playing together, which is called associative. Associative is where in this condition children can play together with other children in one group. Children exchange play materials and languages, there are no goals planned by children to play. Playing cooperation which is as important as the 3 types of play before is support for playing cooperation which is also called cooperative play. Cooperative play is a condition in which children can play cooperation that allows children to play with other children. On playing cooperation there is meaning and purpose in playing, so that children can plan and take roles. On the theme of My Home is My Paradise, children are able to portray themselves as father, mother, brother and sister. They have been able to portray who they are and agree on what role their friends have chosen and played. The four playgrounds can support 4 social skills that are usually owned by children such as MildrenParten's opinion in 1932. From this activity, it can be seen that children can speak fluently even with simple times.

\subsection{Foundation Experience Before Playing}

Read books related to experience or bring in speakers. The teachers read a number of books related to the Sakinah Family, the Prosperous Family, BaitiJannati, Prepare the Manuscripts for the story of My Home is My Paradise. Give ideas on how to use ingredients. The teacher gives ideas on the use of tools and materials in settings :

a. Living Room/Family ; Visiting activities. The teacher mentions various kinds of tools and materials in the living room / family such as: tables, chairs, flower vases, magazines, newspapers, tablecloths. Children are given an explanation of visiting by saying "Assalamualaikum". Similarly, when going to leave home, you must say "Salam". Children in the living room answer "Waalaikumsalam". It aims to recognize and apply the morality of the behavior of the Prophet Muhammad in daily life. For example, when a mother wants to go to the market, say "Salam", dad reads the newspaper in the living room / family. The teacher gave the idea that the living room was only played by 2 children.

b. Prayers in Congregation; The teacher argues that when the Adhan reverberates, all family members must gather in the living room / family to perform the Dhuhr prayer. Before performing the Dhuhr prayer, the teacher asks all children to perform ablution in the space provided. In the living room / family there is one room for prayer activities. There is also a shelf that contains a set of prayer equipment. In the family room setting also provided prayer equipment, such as mukena, sarong, skullcap, prayer rug, Al-Quran in accordance with the number, which is 10 children. The prayer equipment is set up because the theme of playing roles on this occasion is the theme "My Home is Paradise". In this space setting, prayers are held in congregation. Prayer in congregation is carried out introducing children to prayer equipment, recognizing prayer readings, recognizing the sequence of movements in prayer, recognizing prayer procedures, recognizing the call to prayer as a sign of prayer time, knowing iqomah as a sign that prayer will begin, happy and sincere congregational prayers, praying in prayer, focusing on prayer congregation, recognize the number of raka'at prayers, recognize the names of obligatory prayers and sunnah prayers. 
c. Kitchen ; Activities in the kitchen, carried out with cooking activities. The children pretended to turn on the stove, then put the ingredients that could be cooked into the pan, even seen a child pretending to raise the fire when he/she would start cooking and turn off the fire when stating the dish was cooked. The child who acts as a mother is very busy cooking putting food ingredients into the pan. Cooking activities may be played by 2 people. The teacher informed that in the kitchen room there were 2 stoves, small chairs, frying pans, pots, spatula, plastic vegetables and fruits, fish, etc. The teacher initiated a cooking activity played by 2 children, teacher suggested that in this iron room there were mothers and sisters.

d. Dining Room ; In the dining room, the activities carried out are eating together, after pretending, cooked dishes are processed in the kitchen by cooking them. The teacher initiated that in this dining room can be played by 5 children, the teacher initiated that in this dining room there are father, mother, brother, sister, grandparents; teachers initiating activities in the dining room are: Preparing a dining table, putting tableware like plates, glasses, spoons, forks, hand wash, serving cooked dishes that have been cooked in the kitchen, all family members sit sweetly in the dining chair, dad leads the prayer to eat which is followed by mother, brother, sister, grandmother / grandfather: Bismillah, Meaning : In the name of Allah. The whole family eats with order and sharing. After finishing eating, read the prayer after eating. Take care of the cutlery and put it into the kitchen according to the place and clean the table.

e. Shop at the Market; The teacher thought that anyone who shopped, to be cooked at home or eaten at home. Children informed can buy fruits, vegetables and other foods. On the market, after buying have to pay at the cashier. Sellers and cashiers can serve buyers. Buying can use toy money made of paper that has been provided.

\subsection{Foundation Experience During Playing}

a. Give children time to manage and expand their children's playing experience.

The teacher goes around looking at children's play activities. Only to children who need help, the teacher will help the child. When giving a foundation in playing experience, the teacher is passive when there is a possibility that the child will expand his/her playing

b. Examples of appropriate communication. Children at the center macro role-playing, actively chattering about their toys. When there is a talking child that is not understood by his/her friend, the teacher gives a basis for using appropriate communication. Also on this occasion, the teacher provided a foundation for strengthening language and expanding children's language.

c. Improve socialization skills through peer relationships.

Kindergarten Group B, playing a role center is quite active, especially in cooking and shopping in the market. When children are absorbed in their lives, or children fight with friends, here the teacher immediately gives a foundation.

d. Observe and document the development and progress of playing children.

This is important, because it can be a step forward for these children, as part of the evaluation.

\subsection{Foundation Experience After Playing}

After the child plays in the macro role center, the teacher provides a foundation to support the child to recall his/her playing experience. Support children to recall their playing 
experiences and create their playing experiences. This step is done by the teacher after the children are declared to have finished playing, sitting in a circle after playing, encouraging children to talk about their experiences. This step is very important for teachers to do through recalling activities, namely by re-asking what children are playing, by training children to express and experience their experiences. This can expand the vocabulary of children's vocabulary, when the teacher only gives one child the opportunity to recall, even though all the children raise their hands wishing to speak, it looks like the child is disappointed because their wishes are not accommodated in telling their experiences. In the activity of socializing the provision of foundation through playing activities for Education for Young Learners teachers, there are still very few Education for Young Learners institutions implementing the macro role-playing, the teachers are interested in applying macro role-playing. The application of role-playing centers, can be done on Young Learners, because of the low cost. Educational game tools can be used from unused objects at home, which can be donated or lent by parents and do not include consumables. The urgency of playing the macro role is that today people are multi-roles, so that their social roles should not be abandoned.

\section{Conclusion}

Scaffolding can be implemented in various centers. Especially for macro role-playing, it is held in its own center, so role-playing becomes very thick. In the Education for Young Learners environment, it seems difficult to implement role-playing centers, including in providing scaffolding. How do you need to find a center, but it can be a variety of centers, including role-playing centers. Role-playing is not done specifically there is a role-playing center, because it can be modified anywhere, such as when going to see a plane, then there will be talk of role-playing. Pembina Kindergarten has tried in two rooms, the center is changing because of the limited learning space. With the implementation of a separate roleplaying center, it is necessary to apply simpler scaffolding that can be in one center, but can be in the form of a role playing center and other centers. This is a challenge ahead.

\section{References}

[1] Catron and Allen. Early Childhood Curriculum A Creative-Play Model. Second Edition. Ohio : Prentice Hall, 1999.

[2] Docket, Sue and Marilyn Fleer. Play and Pedagogy in Early Childhood : Bending the Rules. Sidney : Harcourt, 2000.

[3] Elirason, Claudia and Loa Jenkins. A Practical Guide to Early Childhood Curriculum. New Jersey : Pearson Education, 2008.

[4] Florida Department of Education. Voluntary Prekindergarten Education Standards. Florida : Department of Education, 2005

[5] James, Spradley. Participant Observation, New York : Holt, Rinehart and Winston. 1980

[6] Karpov, Yuriy. Development Through the Lifespan : A Neo-Vygotskian Approach. In Kozulin, Gindis, Ageyev, and Miller (Ed). Vygotsky's Educational Theory in Cultural Context. Cambridge : Cambridge University Press. 2007.

[7] Musfiroh, Tadkiroatun. Cerdas Melalui Bermain: Cara Mengasah Multiple Intelligence pada Anak Sejak Usia Dini. Jakarta : Grasindo, 2008

[8] Phelp, C. Pamela. Beyond Cribs Rattles : Fully Scaffolding Development Ifants and Todlers. Canada : Kaplan Early Learning Co, 2005

[9] Satori, Djam'an dan Aan Komariah. Metodologi Penelitian Kualitatif, Bandung: Alfabeta, 2009 
[10] Silalahi, Penelitian Studi Kasus. Jakarta : RajaGrafindo Persada, 2009

[11] Siregar, Eveline dan Hartini Nara. Teori Belajar dan Pembelajaran. Bogor: Ghalia Indonesia, 2010.

[12] Strauss, Anselm and Juliet Corbin. Dasar-dasar Penelitian Kualitatif Prosedur, Teknik dan Teori Grounded. Surabaya : Bina Ilmu, 2007

[13] Sue, Bredekemp. Developmentally Appropriate Practice in Early Childhood Programs Serving Children From Birth Through Age 8. Washington : NAEYC, 1999

[14] Sue, Docket and Fleer Marilyn. Play and Pedagogy in Early Childhood : Bending the Rules. Australia : Harcourt, 2000

[15] Sujiono, Yuliani Nurani. Konsep Dasar Pendidikan Anak Usia Dini, Jakarta: Indeks, 2009

[16] The Creative Center for Childhood Research and Training,Inc . Beyond Centers \& Circle Time : Scaffolding and Assessing The Play Of Young Children. Florida : CRRT, 2005.

[17] Yamin dan Sanan. Panduan Pendidikan Anak Usia Dini. Jakarta : GP Press, 2010.

[18] Yin, Robert K. Studi Kasus Desain dan Metode. Jakarta : Raja Grafindo Persada, 2004.

[19] Undang-Undang Republik Indonesia Nomor 20 Tahun 2003 Tentang Si 